\title{
Geographical Information System Mapping Based on Android at Equal Senior High School In Lubuklinggau
}

\author{
Joni Karman ${ }^{1}$, Ema Crisdiyanti ${ }^{2}$ \\ ${ }^{1,2}$ Bina Insan, University Lubuklinggau \\ Jln. Jendral Besar H.M Soeharto Kel Lubuk Kupang \\ jonikarman.mkom@gmail.com, ${ }^{2}$ emahzn2@gmail.com
}

\begin{abstract}
The problem in this study is there is no geographic information system for mapping senior high schools so that there is a misunderstanding inlocation delivery at aqual Senior high schools (SMA) in Lubuklinggau. This research uses data collection methods, by making observations at the research site, conducting question and answer directly to the source, and documentation by reading literature books. The results of the study show that the program on the geographic information system mapping on Android based equivalents on Android at Lubuklinggau the geographical information system is expected to be a solution for the community in finding the location of Senior High Schools in Lubuklinggau. This application was created using the C I framework and also the ionic framework supported by api Google Maps.
\end{abstract}

Keywords: Android, Information,System, Geographic.

\section{Introduction}

In Simply information technology can be said as a science needed to manage information so that information can be searched easily and accurately. The contents of this knowledge can be in the form of techniques and procedures for storing information efficiently and effectively. Information can be said as processed data. Such information can be stored in written form, sound, dead pictures or live images, so that the information can ultimately be in the form of science and knowledge itself. Geographical Information System is a facility to prepare, present and interpret the facts contained on the surface of the earth. For a more specific definition, GIS is a computer system hardware and software configuration specifically designed for the process of acquisition, management and use of kartogafi data.

Geographical Information System is a facility to prepare, present and interpret the facts contained on the surface of the earth. For a more specific definition, GIS is a computer system hardware and software configuration specifically designed for the process of acquisition, management and use of kartogafi data. Based on the reality in Lubuklinggau, there are already many equivalent high schools (SMA), but the people of Lubuklinnggau still don't know much about it. As a small illustration, the community knows that SMA Negeri 3 Lubuklinggau is in the Petanang, but the community does not know its location because in the Petanang area the area is wide and there is also when people visit Lubuklinggau city and they look for a High School equivalent for their intended needs but they do not yet know the location of The equivalent Senior high school. From the description above, it means that there are still many people who do not know the location of the equivalent Senior high school in Lubuklinggau region, this is due to the absence of a geographic information system for mapping equivalent high schools in Lubukliggau.

This background provides an inspiration for the writer to create a mapping solution for Senior high school equivalents in Lubuklinggau to make it easier for the general public, both those who live in the suburbs themselves and the people who 
visit Lubuklinggau to more easily and quickly find the location of equivalent high schools for the desired purposes.

\section{Research Methodology}

In this study the author will design and create a Geographical Information System Mapping for Equivalent Senior High School (SMA) in Lubuklinggau based on Android, so that it can be accessed on android devices to facilitate the public in knowing the location of Senior High Schools in Lubuklinggau only by accessing them on Smartphone Online

\subsection{Literature Review}

\subsubsection{Geographical Information System}

Geographic Information System is a organized collection of software and hardware, geographical data and personnel which designed eficiently to get storing, upgrade, manipulation, analyse and present a reference geographical Information [1]. Geography is a study about eart and the process how to conduct Geography differ place in the eart, explain the shape, and how they make the correlation each other [2].

\subsubsection{Android}

Android is an operation system for mobile device based on linux. Which covers operation system, middleware and android aplication. Android provide platform for developer to reach their aplication, Initialy google inc. In order hand Development Android kit or SKD Android is tool API (Aplication Programming Interface) which use for begin to develop the aplication at android platform using Java Programe language. Android is a software subset for handphone covering middle ware operation system and key aplication which released by google, they are framework, virtual divick, integrated browser and un media as the supporters [2].

\subsubsection{Google Maps API}

Google Maps Android API is a part of Google play service. Google Maps API can insert the map on Android Aplication and do the changing on available map by Google according to our want. The users can see the map which provided by Google and can give a mark on a location with marker [3].

\subsubsection{JSON (JavaScipt Object Notation)}

JSON (JavaScript Object Notation) is the changing data form light, easy to read and write by human, and easy to translate and made (generate) by computer. This form made based on part of language programming Java Script ECMA 262 standart, third edition December 1999. JSON is teks form which do not depend on programming language because use general laguage style by family programe $\mathrm{C}$ include $\mathrm{C}, \mathrm{C}++, \mathrm{C \#}$, Java, JavaScript, Perl, Python etc. So that character, can be ideal JSON as changing data language [4].

\subsection{Development System Method}

The development system method used is the Waterfall Method. According to Rossa and Salahuddin the waterfall method can also be called a sequential linear model or classic life path, providing a sequential or sequential software life cycle approach starting from analysis, design, testing coding, and stages supporters (support) [5]. 


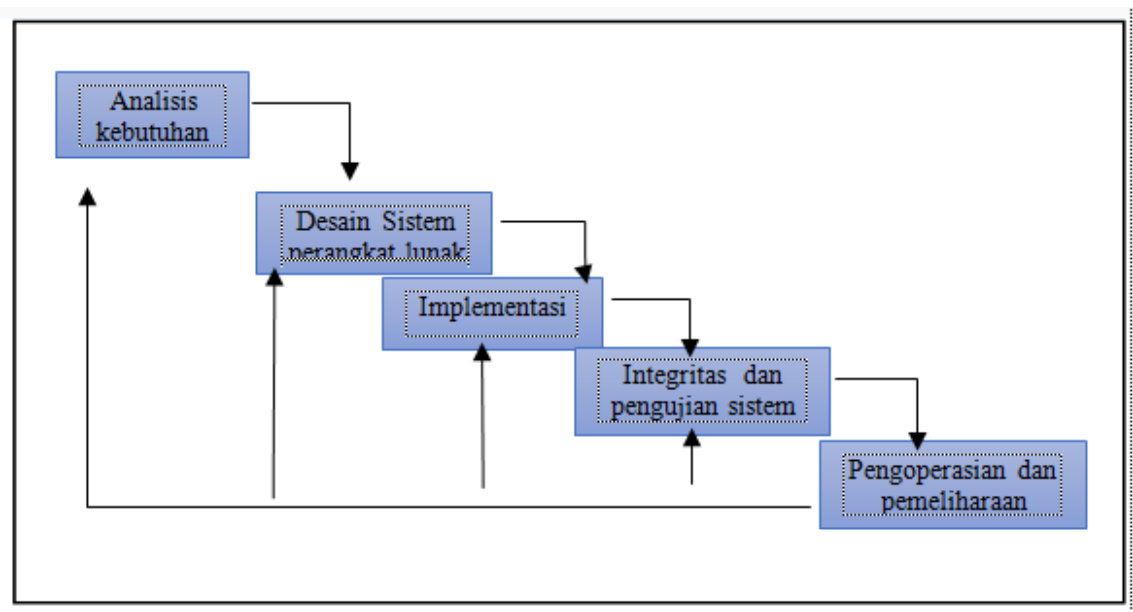

Figure 1. Waterfall Method

In development stage of waterfall (waterfall) consists of several activities which are certainly in accordance with the stages that have been outlined in the system development process. That stage are:

a. Needed Analyse

At this stage the authors analyze the needs of users through interviews, discussions or direct surveys they need applications that can help and facilitate users in knowing / seeing information and the location of equivalent Senior high schools in Lubuklinggau. The author also analyzes that smartphones applications are used by the public or users in the from various versions of Android, so it is also hoped this application of Android Version can be used widely in the community.

b. Software Desain System

At this stage the authors design applications that will be built later, according to the requirements specifications of the needs analysis phase. The author designs or designs the system using UML which consists of Usecase Diagrams, Activity Diagrams, Sequence Diagrams, Class Diagrams, and I / O designs.

c. Implementation

At this stage the authors do the coding process using the CodeIngniter framework and the Ionic Framework based on the design that has been done at the software system design stage.

d. Integrity and System testing

At this stage after the integration of the entire system is tested to check for any failures or errors, then the system testing has been made using the Black Box Testing method.

e. Operation and maintenance

This application stage has been run and done maintenance. Maintenance is included in repairing errors that were not found in the rare past. Improvement of the implementation of the system unit to improve system services as new needs.

\subsection{Needs Analyse And System Design}

\subsubsection{Needs Analyse}

In the needs analysis phase, the author looks at the current system and what is needed in the system and then provides a solution in solving the problem.

a) Needs Analyse

The author analyzes the needs of users through interviews, discussions or direct surveys the need applications can help and facilitate users in knowing / seeing information and location of equivalent high schools in the Lubuklinggau. The 
results of this analysis can be obtained through interviews, discussions or direct surveys.

b) Problem Solving Alternative

As an alternative solution in solving the problem, the authors take a solution by making an application based on Android geographic information systems using the ionic framework programming language.

\subsubsection{System Design}

For system design, the author uses UML (Unified Modeing Language) consisting of Usecase Diagrams, Activity Diagrams, Sequence Diagrams.

a) Usecase Diagram

Usecase Diagram in the geographic information system the mapping of Senior High school in Lubuklinggau based on android consists of 2 actors who play a role, namely Admin and User. The following is a picture of the usecases of the geographic information system for Senior High school mapping in the Androidbased in Lubuklinggau:

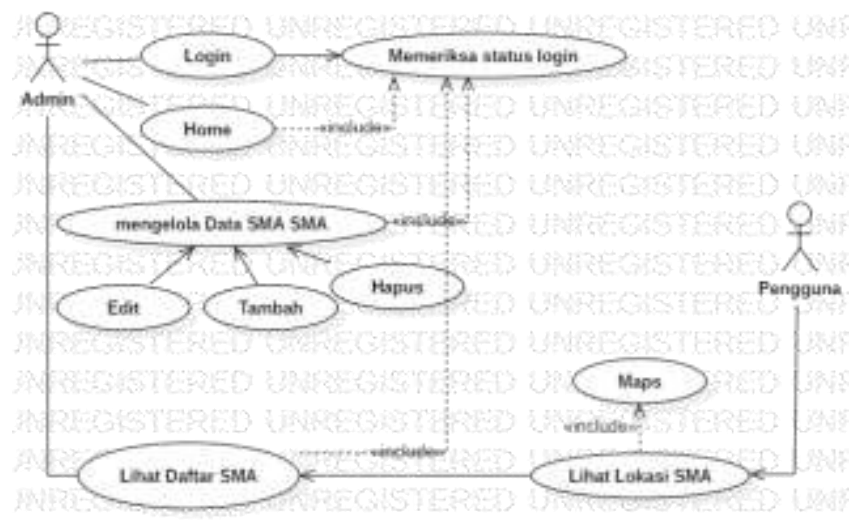

Figure 2. Usecase Diagram

b) Class Diagram

Class diagram is a construction or component of what will be needed in making a system. The following is the class diagram of the system to be built.

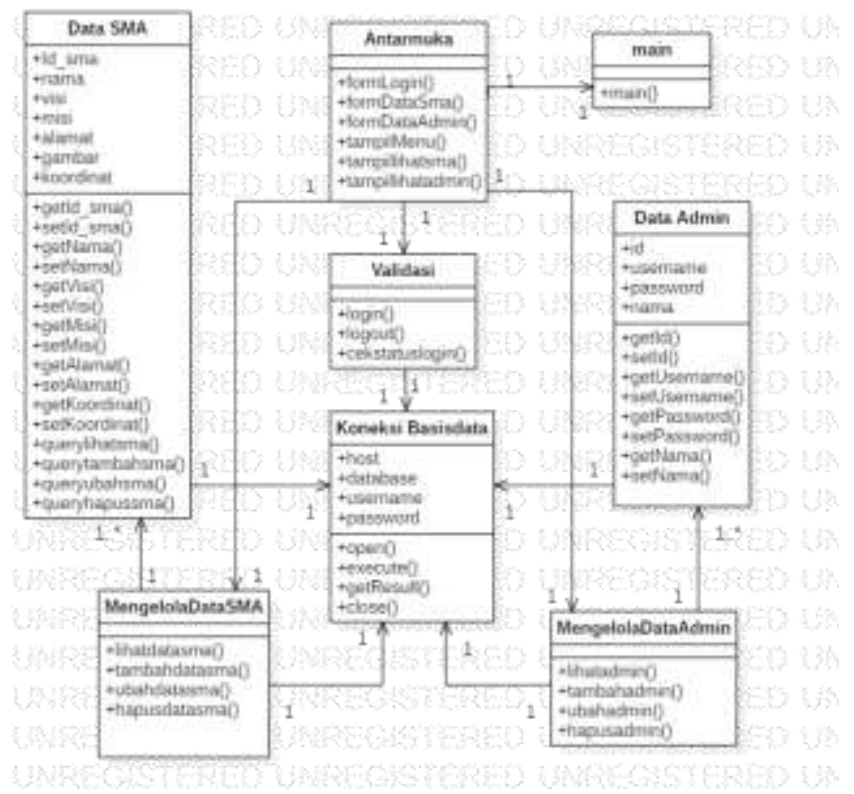

Figure 3. Class Diagram 


\section{Results and Discussion}

\subsection{The Result of Research}

\subsubsection{Login Admin Page}

Admin login page is a page that determines admin access to enter the backend system. GIS Application for Mapping High School Equivalent Based on Android in Lubuklinggau

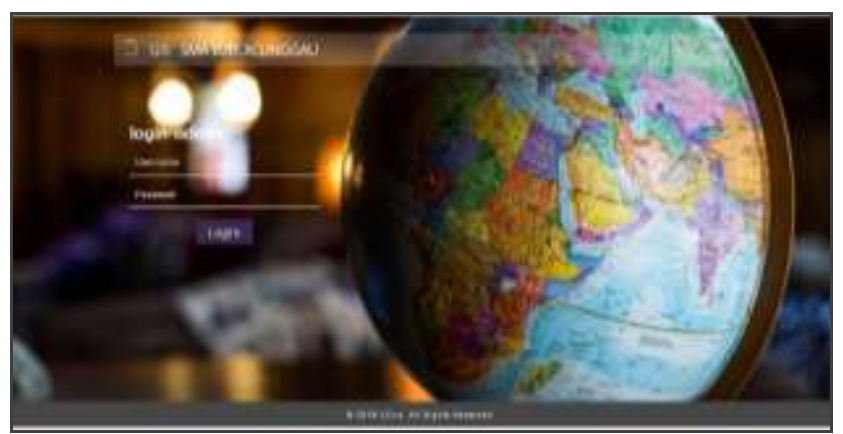

Figure 4. login admin Page

\subsubsection{The Main Page of Application}

The main page of application is the initial display of the backend system of GIS Mapping for High School Equivalents Based on Android in Lubuklinggau, if the login access is successful. On this page there is a high school menu list, on admin data.

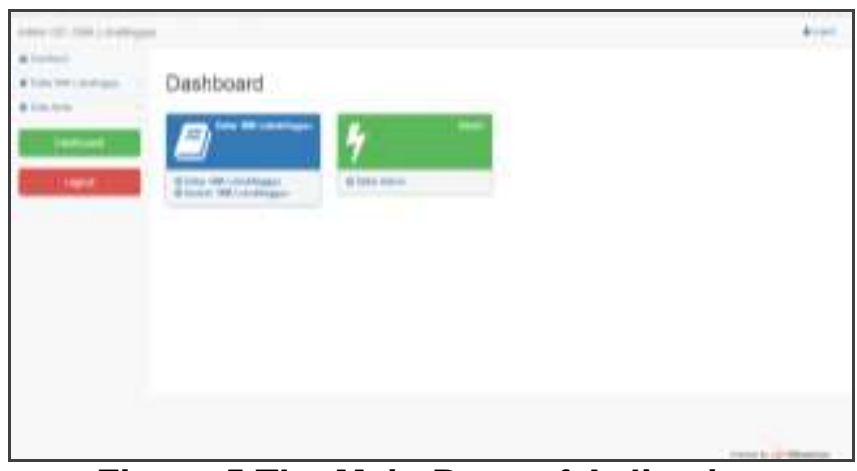

Figure 5.The Main Page of Aplication

\subsubsection{Page of List Senior High School Admin}

The high school list page is a page that contains information about each high school equivalent data in Lubuklinggau

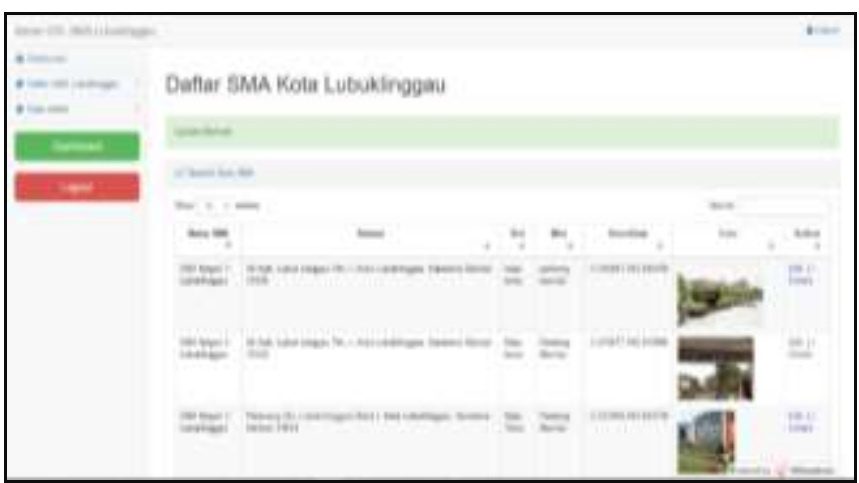

Figure 6. Page of Senior High School admin 


\subsubsection{Page of Added Data Senior High school Admin}

The page added admin high school data is a page for inputting fields about information data for each equivalent high school in Lubuklinggau

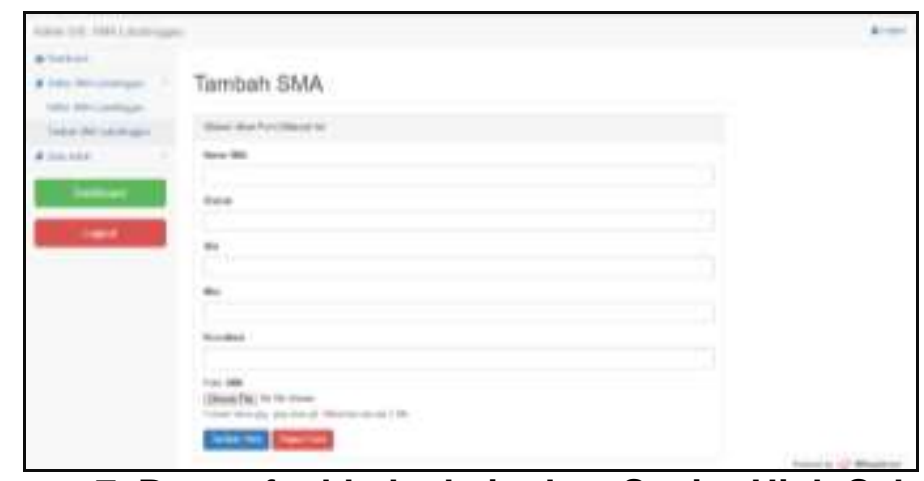

Figure 7. Page of added admin data Senior High School

\subsubsection{Page of Edit Data SMA Admin}

Admin high school data edit page is a page view to change the data in information data fields for each equivalent high school in Lubuklinggau

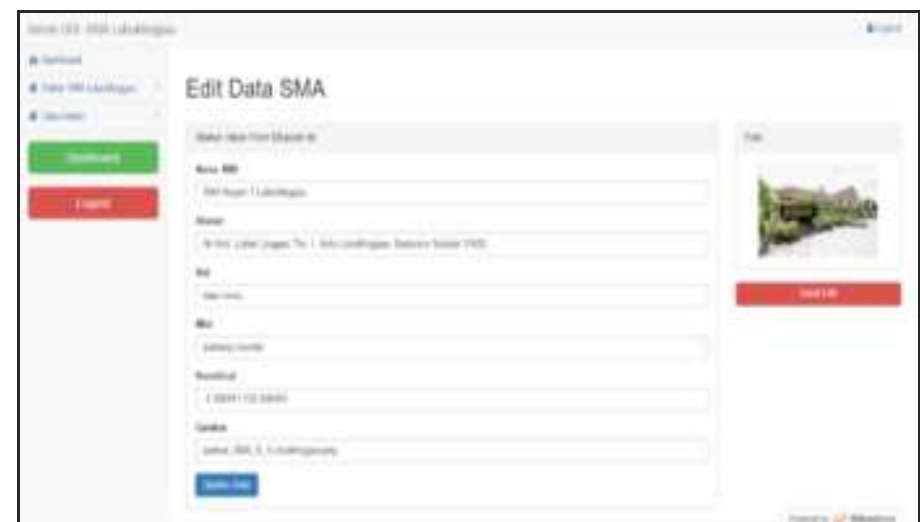

Figure 8. Page of edit data SMA admin

\subsubsection{Display Front Page Application}

Front page display is the first page display that will appear when the user opens this application for the first time.

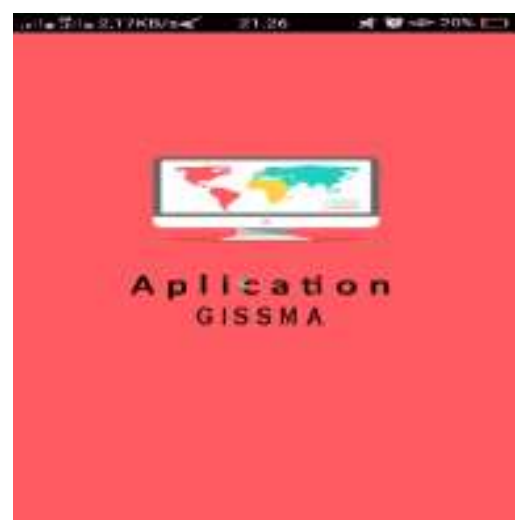

Figure 9. Display Front Page Application 


\subsubsection{The main Page Application}

The Main page is the page that will appear when the user has successfully opened the application.

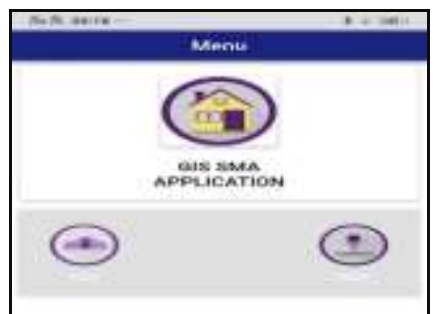

\section{Figure 10. The Main Page Application}

\subsubsection{Display Data Page High School Application}

The application high school data page is the page that will appear when the user opens or clicks the High School List menu in the menu page of the application, then the list data for equivalent high schools in Lubuklinggau will appear

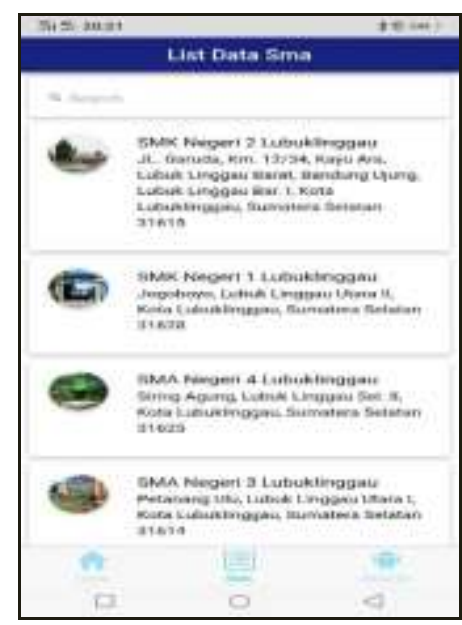

Figure 11. Display the Main Page aplication

\subsubsection{Display Page Detail and Location of Application High School}

The detail page and location of the SMA application are the pages that will appear when the user opens or clicks one of the high school data lists on the SMA data menu page, then the details from the list data of High School equivalent in Lubuklinggau will appear.

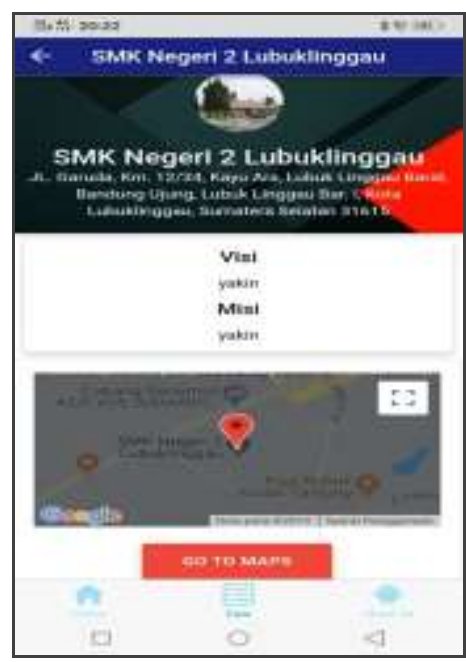

Figure 12. Display page details and application location 


\subsubsection{Display the high school data maps page Application}

The SMA data maps page application is the page that will appear when the user opens or clicks on SMA maps menu at the main page.

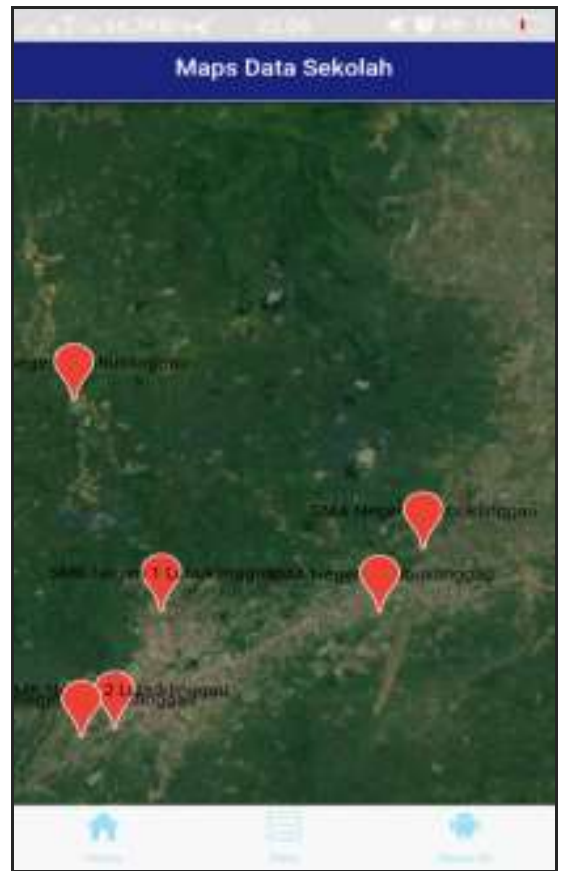

Figure 13. Display the high school data maps page Application

\section{Conclusion}

From the results of the research author did about the Application of Geographic Information Systems Mapping at High School Equivalent Based on Android in Lubuklinggau, the author can conclude as follows:

a) Geographical Information System Application of mapping High School (SMA) Equivalent Based on Android in Lubuklinggaud can be accessed on android devices.

b) This application can assist in delivery information data and the location of equivalent high schools in Lubuklinggau accurately and easily understood.

c) This application can be used as a data collection for high school locations online.

d) By making this application provide experience for researchers in the development of science based on Android-based Geographic Information Systems in order to facilitate the public in finding the location of equivalent high schools in Lubuklinggau

\section{References}

[1] Y. Murya, Pemrograman Android Black Box. Indonesia: Jasakom, 2014.

[2] D. Marlena and H. Aspriyono, "Sistem Informasi Geografis Letak Lokasi Rumah Sakit Dan Apotek Kota Bengkulu Berbasis Android," J. Media Infotama, vol. 10, no. 2, pp. 161-167, 2014.

[3] Kholil, "Pemanfaatan Sistem Informasi Geografis (Sig) Dalam Aplikasi Pelaporan Dan Pelacakan Kejahatan Berbasis Android," J. Teknol. Inf. Dan Komun., vol. 6, no. 1, pp. 1-8, 2017.

[4] A. Juansyah, "Pembangunan Aplikasi Child Tracker Berbasis Assisted Global Positioning System (A-GPS) Dengan Platform Android," J. Ilm. Komput. dan Inform., vol. 1, no. 1, pp. 1-8, 2015.

[5] R. AS and M. Shalahudin, Rekayasa Perangkat Lunak: Terstruktur dan berorientasi objek. Bandung: Informatika, 2015. 


\section{Authors}

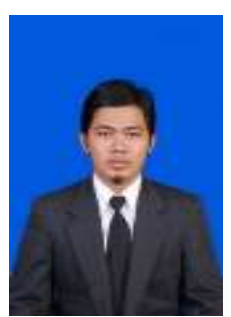

$\mathbf{1}^{\text {st }}$ Author

\section{Joni Karman}

Department of Information System Faculty of Computer Science, Bina Insan University

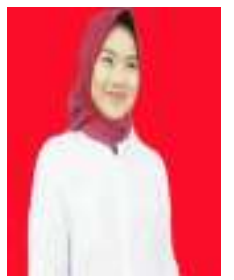

$2^{\text {nd }}$ Author

Ema Crisdayanti

Department of Information System Faculty of Computer Science, Bina Insan University 